\title{
The Dilemma of Taxation Law for Small Farmer
}

\author{
Ismayantika Dyah Puspasari \\ Universitas Nusantara PGRI Kediri. Jl. Ahmad Dahlan No.76, Mojoroto, Kec. Mojoroto, Kota Kediri, Jawa Timur 64112 \\ ismayantikadp@gmail.com
}

ARTICLE INFO

Article history

Received 17 January 2020

Revised 27 April 2020

Accepted 30 April 2020

Keywords

government regulation

farmers

taxpayers
ABSTRACT (10PT)

The purpose of this research is: (1) to find out to what extent the Directorate General of Tax has fully disseminated to all levels of society, especially farmers, regarding the imposition of PP 23 of 2018 for farmers. (2) analyzing tax imposed to farmers if there was no harvest period, which means they do not get income, (3) analyzing the risk of loss to farmers when in a famine. This research uses the descriptive qualitative approach in which the researcher criticized PP 46 of 2013 and PP 23 of 2018 based on the conditions in the field and was supported by various sources. The results of this study indicate that the community is increasingly uneasy with a variety of new regulations especially that the income of village farmers is uncertain. The application of taxation regulation needs to be reviewed so that the existing rule does not burden small farmers.

This is an open access article under the CC-BY-SA license

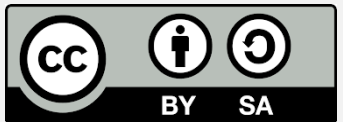

\section{Introduction}

Tax is the most important sector for Indonesia in increasing the development and prosperity of the people, without a tax there is no certainty that state development cannot take place maximally because state revenues will be minimal in number. In fact, the state revenue in 2018 is Rp. 1.539 trillion and the contribution of the tax sector in revenue is Rp. 1.518 trillion or $98 \%$ of total state revenue [1]. Tax revenue, exclusive customs and excise, has made the biggest contribution in the state budget, which continues to increase every year. With the need for large amounts of state revenue, the government tends to continue to increase the sector that is stable in providing income and a large value, namely the sector that comes directly from the public, namely the taxation sector.

The existence of a country in development can never be separated from the participation of the people where one of them is from tax payments. Therefore the relationship between the government and the community as taxpayers is a matter that must be considered. Dissemination to the public to be aware of paying taxes that continue to be activated by the government (which in this case is represented by the Tax Service Office) must be balanced with fair treatment [2]. Therefore, a regulation which contains the rights and obligations of the government as well as the rights and obligations of the public as a taxpayer is provided so that all taxation systems in Indonesia contained in the Taxation Law and Government Regulations can be accounted for administratively and criminally.

SMEs or Micro and Small Enterprises have been developing in Indonesia, both in rural and urban communities. SMES is an economic sector that has such a big role in improving the national economy. For example, almost all districts and cities that are spread evenly in Indonesia already have their own distinctive icons where they move the surrounding human resources to improve the regional economy. Each region already has souvenirs, food, souvenirs and batik, special crafts that have been developed into industrial centers. 
According to Law number 20 of 2008 MSMEs are businesses carried out by individuals or business entities with a certain distribution. Micro Business, namely businesses that have a gross circulation of a maximum of Rp. 300 million a year, small businesses, namely businesses that have a gross circulation of more than Rp. 300 million to Rp. 2.5 billion a year and Medium Enterprises, namely businesses that have a gross circulation of more than Rp. 2.5 billion to with $\mathrm{Rp}$. 50 billion a year [3]. This is the industry and trade sector in Indonesia which has contributed to the increase in the national economy which is so large and directly one of them in the form of tax revenues from the MSME sector. Prior to 2013, precisely before the Government Regulation No. 46 of 2013, for individual taxpayers using the Net Income Calculation Norm. Taxpayers Individuals are required to make records to determine the amount of gross circulation. Calculation norms are determined based on certain types of business, for example, a $20 \%$ trading business. The tax base for commercial businesses is only $20 \%$ of the gross circulation that is obtained after that is transferred according to PPh Article 17 rates. However, after the Government Regulation Number 46 of 2013 which effective July 1, 2013, that all individual and corporate taxpayers who have gross circulation of less than Rp. 4.8 billion rupiah a year must pay income tax of $1 \%$ of turnover (gross circulation) and this tax is final [4].

In 2018, the Directorate General of Taxes reduced tariffs for micro and small businesses to $0.5 \%$ written in PP 23 of 2018 [5] with the aim of providing a tax burden relief for small and micro businesses. This Government Regulation replaces PP 46 of 2013 so that many business operators feel that they are made easy on tax obligations. On the other hand there is a lot of dilemma in the enforcement of this Tax Regulation which is the basis of Tax Calculation (DPP) is gross circulation means that this tax calculation does not take into account losses, operational costs or other costs so that after all the taxpayer conditions both loss or profit must pay a tax of $0,5 \%$ of turnover. Like the two sides of the coin where on one hand this regulation will in time benefit taxpayers who have large profits, but will harm taxpayers who have small profits or may suffer losses. This is part of the understanding of PP 46 of 2013 and PP 23 of 2018 that are applied to MSMEs, then how is the implementation for Indonesian farmers where they get income that might be said to be more tragic than MSMEs. In accordance with the law that this tax rate applies to the taxpayers of individuals and entities that have income below Rp. 4.8 billion. Then what about Indonesia, which has been referred to as a maritime country, which in the 90s Indonesia has become a "Swa Sembada Pangan" country, Indonesia which has exported rice and sugar and Indonesia which has been victorious in its agricultural sector. Is the past and present of Indonesia still the same? The answer is certainly not, Indonesia has now turned into an industrial and trade country, no longer an agricultural country that excels in agriculture and fisheries. Large-scale Indonesian farmers may not have a problem with the enactment of PP 23 of 2018, they own land that may have acres of land, but many small farmers in the village only have a plot of land that is approximately 100ru $(1400 \mathrm{~m} 2)$ which is the backbone of the family small, giving an uncertain income in waiting for the harvest period of 2-4 months.

If the MSME income tax is set and put into the category of Government Regulation No. 23 of 2018 , then how tax regulations are applied to the agricultural sector where the majority of the community's income in the village is from farming and trading agricultural products. Farmers themselves are in accordance with the understanding of the Taxation Law No. 16 of 2009 entered as an Individual Taxpayer. Income obtained is uncertain, meaning a farmer does not get income every month, because the income they get is based on the harvest season. Can be 2-4 months depending on what they are planting whether vegetables, corn, and rice.

By seeing who is the subject of tax since the enactment of Government Regulation Number 46 of 2013 and now PP 23 of 2018, namely individuals who earn income not exceeding Rp 4.8 billion in a year, farmers with a turnover below Rp 4.8 billion a year entered into PP No. 23 of 2018 with the amount of the tax rate is $0.5 \%$ of gross circulation without reducing any costs including loss costs. However, most farmers in Indonesia (in this case the village where the author lives as a sample) do not know about taxation for farmers. Let alone their obligations as taxpayers, what is 
their taxation is still very minimal with that knowledge. If they have become taxpayers, how will they pay their taxes through whom, how to calculate it, how will they report it and their other obligations, most of them will lack knowledge. Then whether this is in accordance with the tax objectives contained in its understanding (Law Number 28 of 2007) where the tax as much as possible is used for the prosperity of the people.

Understanding and Characteristics of Taxes [6] :

1. Mandatory contributions to the country owed by individuals or entities

2. Forcing

3. Do not get rewarded directly

4. Used for the needs of the country for the prosperity of the people

Indonesian people, most of whom earn a living as farmers, do not seem to be prosperous by taxes but are impoverished by taxes. To fulfill their daily lives, they are still very under simplicity, even their children have to help go to the fields and work. Then whether with the imposition of Income Tax for those whose income when compared to the Individual Taxpayers of employees who are very much different, this can also be said to be unfair. We just make the comparison as follows:

Table 1 Comparison of Tax Imposition of Individuals

\begin{tabular}{|c|c|c|}
\hline Income & Employee Taxpayer & $\begin{array}{l}\text { Taxpayer Small Farmer with an } \\
\text { assumption of } 100 \mathrm{ru} \text { corn fields }\end{array}$ \\
\hline 1 st month & $\operatorname{Rp} 3.000 .000$ & - \\
\hline 2nd month & $\operatorname{Rp} 3.000 .000$ & - \\
\hline 3rd month & $\operatorname{Rp} 3.000 .000$ & $\operatorname{Rp} 4.500 .000$ \\
\hline Average Income a month & $\operatorname{Rp} 3.000 .000$ & $\mathrm{Rp} 1.500 .000$ \\
\hline Conclusion & PPh Rp 0,- & $\begin{array}{l}\text { Taxed } 0,5 \% * \operatorname{Rp} 4.500 .000=\mathrm{Rp} \\
22.500,-\end{array}$ \\
\hline Total net income received & $\operatorname{Rp} 9.000 .000$ & $\operatorname{Rp} 4.477 .500,-$ \\
\hline
\end{tabular}

From table 1, it can be seen that there is an injustice in taxation between individual employees and private entrepreneurs, which in this discussion are small farmers. This should be the basis for consideration for the government to review PP 46 of 2013 for small businesses. There are many weaknesses in this government regulation, which is why if there must be an employee named PTKP, whereas PTKP in Government Regulation Number 23 of 2018 is not valid at all. So much dilemma in the application of PP 46 in 2013 and PP 23 in 2018.

The objectives in this study are to find out whether farmers who have income from direct farming must automatically become taxpayers; to find out to what extent the Director General of Taxes that have been represented by the KPP in each working area has fully disseminated to all levels of society, especially farmers regarding the imposition of PP 23 of 2018 for farmers, and to analyze the taxation for farmers who are not in the harvest period which means they do not get income.

\section{Method}

Taxpayer compliance is a condition where taxpayers fulfill all tax obligations and carry out their tax rights [7]. There are two types of tax compliance, namely formal compliance and material compliance. Formal compliance is a condition where taxpayers fulfill tax obligations formally in accordance with the provisions of tax legislation. Whereas material compliance is a condition in which the Taxpayer substantively or essentially fulfills all material provisions of taxation. Tax compliance implies awareness of tax payers for their obligations where the government itself provides more facilities for taxpayers for the existence of account representatives [8]. 
Burton (2005) [9] explains that there are three compliant taxpayer criteria based on taxation regulations, namely (1) timely submitting tax returns for all types of taxes in the last two years, (2) Not having tax arrears for all types of taxes, unless it has obtained permission to supervise or delay payments tax, and (3) Not having been sentenced for committing a criminal act in the taxation field for a period of ten years.

Income Tax subject according to PP 23 of 2018, are:

1. Private person;

2. Entity, not including Permanent Establishments (BUT), which receives income from businesses with a gross profit (turnover) that does not exceed 4.8 billion in one tax year.

Where in PP 23 of 2018 there are several taxpayers who are not the object of Income Tax PP 23 of 2018 that must meet the following criteria:

1. Income from services in connection with free employment, such as: doctors, advocates or lawyers, accountants, notaries, PPAT, architects, music players, presenter;

2. Income from businesses subject to final income tax (Article 4 paragraph 2), such as boarding room rent, house rent, construction services, oil and gas business income tax, building buying and selling, etc., which are regulated based on separate Government Regulations.

Exceptions to the subject of income tax according to PP 23 of 2018 are:

1. A private person who carries out business activities in trade and / or services using means that can be assembled and used part or all of the place for public use. For example: peddlers, hawkers, tent stalls in the sidewalk area, and the like.

2. Entities that have not yet operated commercially or who within one year after operating commercially obtain gross circulation exceeding Rp. 4.8 billion.

In this study using descriptive qualitative research that is research used to explore and analyze what happens in the field which is then examined. In this study using 4 main stages of research, namely:

1. Identification stage

Explain the phenomenon of research, the formulation of the problem and the purpose of research and then the researcher conducts a literature study and identifies the variables to be studied.

2. Data collection stage

3. Data processing stage

The data obtained will be separated based on an explanation from the informant.

4. Analysis phase and conclusions

Researchers will explain descriptively from the results of interviews and observations of taxpayer opinions.

Information Collection and Analysis Process includes :

1. Observation

Data collection techniques by means of observation carried out by researchers because this research is concerned with human behavior and work processes.

2. Interview

The interview process is used in this study because the researcher wants to conduct a preliminary study to find issues that must be investigated in depth on an issue or theme raised in the study. There is a belief in researchers themselves that later what was stated by the research subjects (taxpayers) to researchers is true and can be trusted so that the results are used as the main source in writing research results.

3. Documentation

Researchers do documentation by collecting information that can be obtained through facts stored in the form of taking photos during interviews, the results of meetings, journals of activities and so on. Data in the form of documents like this can be used to dig up information that occurred in the past. 
In drawing conclusions, this qualitative research is delivered narratively, namely by using explanations in the form of words. In narrative delivery, conclusions are made based on data obtained, both from observations, interviews and documentation conducted by researchers.

\section{Results and Discussion}

Along with the increasing number of Indonesian people, the greater the responsibility of the government to prosper the people both in all fields such as education, health, and the economy. Of course in improving welfare it is not enough to have a capable leader but the amount of State Budget must be increased every year to strengthen national resilience and improve people's welfare and state development. Of course, by achieving this goal, it is necessary to increase national income by stabilizing the income of several sectors that can be relied on by the government, one of which is the taxation sector. In 2018 alone, the tax sector contributed $98 \%$ of the total state revenue. Of course this is a clear example of government efforts to increase revenues in certain sectors that can be relied upon.

Various government regulations in the tax sector began to be improved in order to curb naughty taxpayers by embezzling their income aimed at minimizing the amount of tax they owe. Many persons who save their assets abroad in order to avoid income tax. Various government regulations are issued in an effort so that those who have tried to harm the country by embezzling their assets and taxes can be found and obey the rules, be more transparent in reporting their assets and not harm the country. For example, one of the Government Regulations that has surprised business operators is Government Regulation Number 46 of 2013. Government Regulation Number 46 of 2013 concerning stipulating that Individual Entrepreneurs and Agencies that obtain gross circulation do not exceed Rp 4.8 billion, they will be subject to income tax as much as $1 \%$ of the gross circulation obtained during such tax period. In 2018, the Government issued Government Regulation No. 23 of 2018, which took effect on July 1, 2018, replaces PP 46 of 2013.

SMEs has automatically entered into the list of PP tax subject 23 of 2018. Over time for several months and years, socialization continues to be carried out by the Tax Service Office in accordance with its working area. Various outreach activities are carried out more on the SME industry groups and the Indonesian Chamber of Commerce so that taxpayers obey the rules. Actually, one of the reasons for the government to apply a tariff of $0.5 \%$ of the turnover of course there is basically one of them is to simplify the calculation so that the minimum taxpayers of accounting only need to record and directly calculate the amount of $0.5 \%$ tax only. But on the other hand this provision is burdensome for some circles whose business has not gone well [10] . So far the socialization carried out to the SMEs has been very good because they have been able to implement and comply with PP 23 of 2018.

However, the problem in this study is the small farmers who are also included in the OP Taxpayer list and participate in the PP tariff 23 of 2018 , which is $0.5 \%$ of turnover. If farmers are indeed part of this PP, but in reality very little socialization is carried out in the villages and can even be said to have never been. Then if it is deliberately never carried out tax socialization, whether the farmers will be wrong if one day he will get a tax bill. Then where are the rights and obligations of farmers there are no clear boundaries. If a regulation can be logic, then village farmers should not be included in PP Taxpayer 23 of 2018 because they are not equipped with knowledge that is not their need. If indeed the government is serious about implementing a Government Regulation on taxation and it must be implemented in all sectors and business units regardless of whether small or large businesses, then the government must review and fully implement loyalty on the regulations that have been made. The socialization must be carried out to all groups of people both in urban and rural areas.

The third dilemma is how to pay taxes in the months not in harvest? This is certainly different from the SMEs, although their income is uncertain every month, but at least every month they earn whatever amount of income. Whereas for farmers, both large and small farmers, if not in the harvest period, the amount of $\mathrm{PPh}$ payable is zero (0), but they have responsibilities during the harvest. It seems unfair for small farmers, where in one harvest their income to replace fertilizer 
operations and workers is sometimes not enough. When compared with individual employee taxpayers, it is considered unfair, we can illustrate this as follows.

Table 2. Comparison of Income Tax Article 17 and PP 23 of 2018 for Individual Taxpayers

\begin{tabular}{|c|c|c|c|c|}
\hline \multirow[t]{2}{*}{ Income } & \multicolumn{2}{|c|}{ Employee Taxpayer } & \multicolumn{2}{|c|}{$\begin{array}{l}\text { Taxpayer Small Farmer with an } \\
\text { assumption of } 100 \mathrm{ru} \text { corn fields }\end{array}$} \\
\hline & Income & Tax & Income & Tax \\
\hline $1 \mathrm{st}$ month & Rp 3.000 .000 & 0 & - & 0 \\
\hline 2nd month & Rp 3.000.000 & 0 & - & 0 \\
\hline 3rd month & Rp 3.000.000 & 0 & Rp 4.500.000 & Rp 22.500 \\
\hline $\begin{array}{l}\text { Average Income a } \\
\text { month }\end{array}$ & Rp 3.000.000 & 0 & $\operatorname{Rp} 1.500 .000$ & RP 7.500 \\
\hline Conclusion & \multicolumn{2}{|c|}{$\mathrm{PPh} \mathrm{Rp} 0,-$} & \multicolumn{2}{|c|}{$\begin{aligned} \text { Taxed } & 0,5 \% * \operatorname{Rp} 4.500 .000 \\
= & \mathrm{Rp} 22.500,-\end{aligned}$} \\
\hline $\begin{array}{l}\text { Total net income } \\
\text { received }\end{array}$ & \multicolumn{2}{|c|}{ Rp 9.000.000 } & \multicolumn{2}{|c|}{ Rp 4.477.500,- } \\
\hline
\end{tabular}

From Table 2, it can be explained that employees with an income of Rp. 3,000,000 are not required to become taxpayers, but instead small farmers are seen earning Rp. 4,500,000 where the income is earned every 3 months or if an average of $\mathrm{Rp}$. 1,500,000 a month is required to become an individual taxpayer. When viewed from the nominal point of view of numbers like this, whether existing government regulations can be said to be fair and can prosper the people. All lay people will declare unfair. Indeed, the two different cases cannot be compared completely because they have their own laws and government regulations, but when viewed from a nominal point of view, it is natural that the people demand justice in the imposition of income tax.

Then, when farmers experience famine or losses which cannot be predicted, such as the results of their fields being handed over by pests as a whole or maybe a rainstorm that is so large that they have to have their entire paddy destroyed without giving any income at all. Of course if they do not generate income or in other words crop failure then the amount of income tax payable is zero (0). But if they still get income but if they are calculated it turns out they are losing money because the operational costs (seeds, fertilizer and labor costs) are greater than the yield then they still have the obligation to pay their income tax of $0.5 \%$ of the gross income of the harvest. This is one of the weaknesses of Government Regulation No. 23 of 2018 in all industrial and trade sectors both MSMEs and farmers.

In the taxation dilemma, the victims in the confusion are small farmers. Those with a lack of knowledge and insight are required to fulfill obligations as taxpayers for their income that is uncertain and of little value. If it should be reviewed, there needs to be a dividing line that can be used as a benchmark for who is obliged to become a Individual Taxpayers for PP 23 of 2018 and who is not a taxpayer of this Government Regulation. For example, determining the average monthly gross income range of Individual Entrepreneur Taxpayer Rp. 3,000,000, so if a farmer has a small income like Rp. 4,500,000 in a harvest every 3 months he is not obliged to pay income tax.

\section{Conclusion}

Taxpayers have the obligation to pay their income tax based on PP 23 of 2018 which is valid from July 1, 2018 by paying tax payable of $0.5 \%$ of turnover (gross income). Despite the fact that farmers are included as taxpayers, almost all farmers in the villages do not register themselves as taxpayers. The lack of socialization and information, is one of the reasons why PP 23 of 2018 has not been able to be fully implemented, especially for village farmers. If farmers get a harvest every 3-4 months with a total income of around Rp 2,000,000 to Rp 10,000,000 in one harvest, can they be considered as taxpayers as a whole if compared to individual employees who have obligations as taxpayers if the minimum income is IDR 3,000,000 per month. The application of this taxation regulation needs to be reviewed so that the existing regulation does not burden small communities, especially for farmers. 
The hope for the government is to review PP 23 of 2018 that in the presence of this PP many people will be troubled even though at present they do not know about it. This will inevitably occur in line with government tips and efforts to continue to improve taxpayer compliance in all corners of the country.

\section{Acknowledgment}

Alhamdulillahi rabil 'alamin, I thank Allah SWT for health, fortune and fluency in meetings and collecting data. I thank also parents, relatives and friends of lecturers who have provided support both in prayer and others. I especially thank the exclusive village community of Tegowangi Village who has provided opportunities for discussion.

\section{References}

[1] K. Keuangan, "Laporan Tahunan Kementerian Keuangan Tahun 2018," Jakarta, 2018. [Online]. Available: http://www.kemenkeu.go.id/,.

[2] I. D. Puspasari, E. Puspita, and D. A. Paramitha, "Cinta UMKM : Sadar Sepenuhnya Atau SetengahSetengah (?)," 2017, [Online]. Available: https://www.academia.edu/36743641/CINTA_UMKM_SADAR_SEPENUHNYA_ATAU_SETENG AH-SETENGAH_.

[3] Kementerian Keuangan Republik Indonesia, Susunan Dalam Satu Naskah Undang-Undang Perpajakan. 2013, p. 484.

[4] K. Keuangan, PP 46 TAHUN 2013. Indonesia, 2013.

[5] K. Keuangan, PP 23 / 2018 - Pajak. 2018, pp. 1-9.

[6] I. A. Indonesia, Modul Brevet Pajak Terapan A dan B. 2013.

[7] S. Nurmantu, Pengantar Perpajakan. Jakarta: Jakarta Granit, 2005.

[8] I. D. Puspasari, E. Puspita, and D. A. Paramitha, "Account Representative Kepatuhan Wajib Pajak (?),” vol. 11, no. 1, pp. 9-17, 2017, doi: https://doi.org/10.32812/jibeka.v11i2.55.

[9] Amilin;Nina Anisah, "Persepsi Peran Account Representative pada Tingkat Kepatuhan Wajib Pajak," vol. 11, no. 1, pp. 9-17, 2008, doi: https://doi.org/10.32812/jibeka.v11i2.55.

[10] M. Wahyudi and E. Kartikaningdyah, "Perbandingan Perhitungan, Penyetoran, dan Pelaporan Pajak Penghasilan ( PPh ) Badan menurut Undang-Undang no 36 tahun 2008 dan Peraturan Pemerintah No 46 Ttahun 2013 pada PT XXX. Tinjauan Pustaka,” J. Akuntansi, Ekon. dan Manaj. Bisnis, vol. 2, no. 1, pp. 24-33, 2014, [Online]. Available: https://jurnal.polibatam.ac.id/index.php/JAEMB/article/view/129/120. 
- This page is intended empty- 